\title{
Deteksi Foreground Dan Background Pada Kematangan Buah Di Pohon Menggunakan Metode K-Means Clustering
}

\author{
Andhika Ramadhan ${ }^{1)}$, Nurul Fadillah ${ }^{2)}$ \\ ${ }^{1)}$ Mahasiswa Progam Studi Teknik Informatika, Universitas Samudra \\ email : andhika.ramadhan44@gmail.com \\ ${ }^{2)}$ Dosen Progam Studi Teknik Informatika, Universitas Samudra \\ email : nurulfadillah@unsam.ac.id
}

\begin{abstract}
Cara Sitasi: Ramadhan, A., \& Fadillah, N. (2019, Maret). Deteksi Foreground Dan Background Pada Kematangan Buah Dipohon Menggunakan Metode K-Means Clustering. (S. Dalis, Ed.) Paradigma - Jurnal Komputer dan Informatika, 21(1), 103-106. doi:10.31294/p.v21i1.5106
\end{abstract}

\begin{abstract}
In this era of technological development, many of the latest technologies have been discovered. One branch of technology that is growing rapidly at this time is in digital imagery. The use of digital images in everyday life is very much, so the use of digital images greatly helps human work. Just an example in agriculture. In the field of agriculture digital image is very useful, namely in harvesting the number of apples. Conventionally, apple farmers will not know how many apples are ripe on an apple tree. But using a digital image of an apple farmer will know how many ripe apples to harvest. By separating between the foreground and background by using K-Means Clustering, the foreground (apple) and background (leaves) will be distinguished. In the clustering background (background) only leaves will appear, while the apples will be blackened to distinguish between the foreground and the background. Whereas in the clustering background (background) only leaves will appear, while the apples will be blackened to distinguish between the foreground and the background.
\end{abstract}

Keyword: Tomato Fruit, Digital Image Processing, Foreground, Background, K-Means Clustering

\section{PENDAHULUAN}

Perjalanan pengembangan keilmuan dalam tema pengolahan citra hingga saat ini mengalami perkembangan yang signifikan dan senantiasa terus dilakukan penelitian mulai dari pengamatan dan analisis dasar hingga tingkat penggunaan implementasi atas sebuah rancangan program terpadu dan kompleks. Penelitian dalam lingkup pengolahan citra ini memicu akan perkembangan industri yang berbasis gambar seperti perangkat foto, kamera digital, serta teknologi yang berkaitan dengan kompresi citra, penemuan kembali informasi citra, penyisipan informasi dan lain sebagainya.

Kematangan buah pada umumnya ditentukan berdasarkan beberapa parameter, diantaranya adalah dari parameter ukuran, berat, ciri warna, keharuman dari buah tersebut, dan lain-lain.Parameter kematangan dari sisi warna kulit pada buah merupakan salah satu faktor penting di dalam identifikasi kematangan buah. Banyak permasalahan yang timbul ketika melakukan identifikasi kematangan buah secara tradisional. Bagi petani buah, tingkat kematangan ini sangat mudah mereka bedakan, tetapi bagi orang awam tentu akan mengalami banyak kesulitan. Masalah ini akibat sifat manusia yang memiliki beberapa kelemahan, diantaranya adalah kelemahan yang diakibatkan keterbatasan fisik maupun indera penglihatan sebagai penentu tingkat kematangan seperti penilaian oleh manusia yang bersifat subyektif dan tidak konsisten sehingga dapat berbeda dari satu penilai dengan penilai lainnya (Iswahyudi, 2010).

Perkembangan teknologi informasi memungkinkan identifikasi kematangan buah bahkan deteksi terhadap jenis buah dengan bantuan komputer salah satunya adalah dengan cara melakukan segmentansi melalui deteksi foreground dan background pada citra buah menggunakan metode K-Means Clustering. Dengan metode ini mampu mengelompokkan langsung suatu data sesuai nilai ciri yang ada. Penggunaan algoritma K-Means digunakan dengan cara memisahkan data yang dianalisa dan mengelompokannya.

Foreground dalam bahasa Indonesia berarti latar depan. Jika background terlihat dibagian belakang dari objek utama, maka foreground sudah pasti berada dibagian depan objek. Ya, dibagian depan dan penempatannya sebenanrya bisa cukup menarik 
namun banyak fotografer yang enggan menempatkan foreground. Sebagai contoh foreground adalah ketika Anda memotret manusia ditaman, dengan latar belakang tumbuh-tumbuhan namun didepan objek terdapat tumbuhan lagi meski tidak sampai menutupi objek utama. Itulah yang disebut foreground. Terkadang foreground sering terlihat pada jenis foto tertentu seperti foto landscape, arsitektur bahkan modeling (Wahyudi, Suhartono, \& Pramunendar, 2018).

Background dalam bahasa Indonesia berarti latar belakang. Dalam sebuah foto dipastikan memiliki sebuah latar belakang dari objek utama. Sebagai contoh Anda memotret seseorang wanita diperkebunan, maka yang menjadi background adalah area perkebunan, atau apa saja yang terlihat dibelakang objek utama. Banyak orang memanfaatkan background untuk menunjukan dimana mereka berada, semisal ketika sedang berwisata atau mengunjungi tempat menarik. Background mengindikasikan bahwa seseorang pernah berada ditempat tertentu, berada didekat tempat tertentu maupun melihat tempat tertentu. Sebuah foto kehilangan background ketika objek yang di adalah elemen yang datar (flat) seperti dinding, memotret tanah dari atas, dan segala objek yang tidak memungkinkan adanya latar belakang (Wahyudi et al., 2018).

\section{METODOLOGI PENELITIAN}

Pada penelitian ini ada beberapa tahap yang akan dilukan untuk membedakan antara foreground (latar depan) dan background (latar belakang) dengan menggunkan metode K-Means Clustering. Hal pertama yang harus dilakukan yaitu dengan mengumpulkan data-data yang akan diuji pada penelitian ini, data-data yang akan diuji pada penelitian ini yaitu pohon apel yang dimana pohon apel tersebut terdapat buah yang telah matang. Kemudian melakukan analisa dan perancangan sistem yang akan dibuat dengan menggunakan bahasa pemrograman MATLAB.

Kemudian dilakukan pengujian terhadap sistem yang akan dibuat pada data-data yang telah dikumpulkan, yaitu yaitu pohon apel yang dimana pohon apel tersebut terdapat buah yang telah matang dengan menggunakan bahasa pemrograman MATLAB. Ketika melakukan proses pengujian terhadap datadata yang telah dikumpulkan maka data awal diinput terlebih dahulu. Kemudian data yang telah diinputkan ditampilkan untuk melihat bagaimana data awal yang akan diuji. Kemudian data awal tersebut di proses dengan menggunakan metode $\mathrm{K}$ Means Clustering untuk membedakan antara foreground (latar depan) dan background (latar belakang). Kemudian setelah dilakukan pengujian data awal dengan menggunakan metode K-Means
Clustering maka akan ditampilkan hasil clustering menggunakan metode K-Means Clustering dan terlihat perbedaan antara foreground (latar depan) dan background (latar belakang)

K-Means termasuk dalam metode Data Mining partitioning clustering yaitu setiap data harus masuk dalam cluster tertentu dan memungkinkan bagi setiap data yang termasuk dalam cluster tertentu pada suatu tahapan proses, pada tahapan berikutnya berpindah ke cluster lain. K-Means memisahkan data ke $\mathrm{K}$ daerah bagian terkenal karena kemudian dan kemampuannya untuk mengklasifikasi data besar dan outlier dengan sangat cepat (Agustin, Fitria, \& S, 2015).

Dalam penyelesaiannya, algoritma $K$-Means akan menghasilkan titik centroid yang dijadikan tujuan dari algoritma K-Means. Setelah iterasi K-Means berhenti, setiap objek dalam dataset menjadi anggota dari suatu cluster. Nilai cluster ditentukan dengan mencari seluruh objek untuk menemukan cluster dengan jarak terdekat ke objek . Algoritma K -means akan mengelompokan item data dalam suatu dataset ke suatu cluster berdasarkan jarak terdekat (Agustin et al., 2015).

Penerapan pada metode K-Means Cluster Analysis, data yang bisa diolah dalam perhitungan adalah data numerik yang berbentuk angka. Sedangkan data selain angka juga bisa diterapkan tetapi terlebih dahulu harus dilakukan pengkodean untuk mempermudah perhitungan jarak /kesamaan karakteristik yang dimiliki dari setiap objek. Setiap objek dihitung kedekatan jaraknya berdasarkan karakter yang dimiliki dengan pusat cluster yang sudah ditentukan sebelumnya, jarak terkecil antara objek dengan masing-masing cluster merupakan anggota cluster yang terdekat. Setelah jumlah cluster sudah ditentukan, selanjutnya dipilih sebanyak 3 objek secara acak sesuai jumlah cluster yang dibentuk sebagai pusat cluster awal untuk dihitung jarak kedekatannya terhadap semua objek yang ada (Ediyanto, Mara, \& Satyahadewi, 2013).

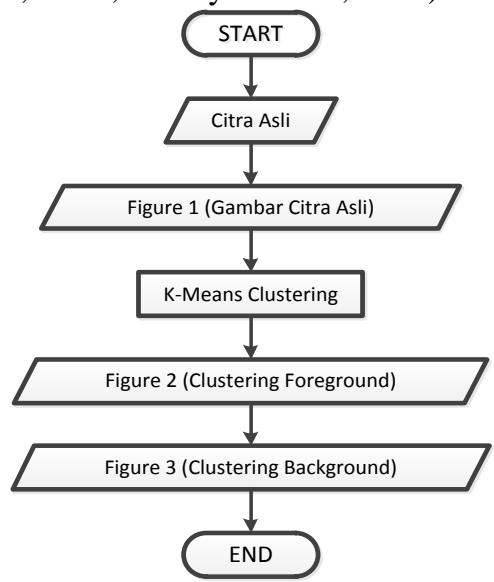

Gambar 3.1 (Perancangan Sistem Penelitian

Foreground dan Background menggunakan $K$ Means Clustering) 


\section{A. Input Citra Asli}

Data uji yang akan diuji pada penelitian ini yaitu pohon apel yang dimana pada pohon apel ini terdapat beberapa buah apel yang telah matang.

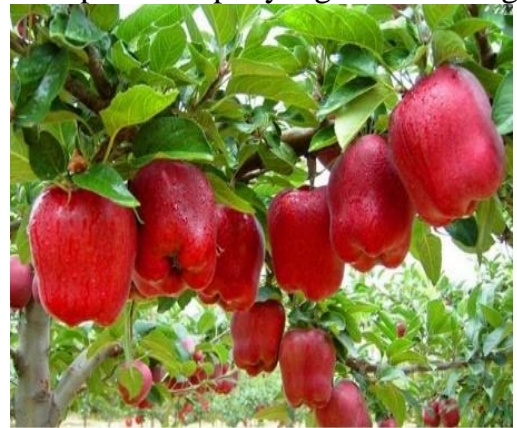

Gambar 3.2 (Pohon Apel)

\section{B. Hasil Output Citra Asli}

Data uji yang telah diinput pada sistem yang akan diuji kemudian ditampilkan terlebih dahulu untuk melihat bagaimana data awal yang akan diuji

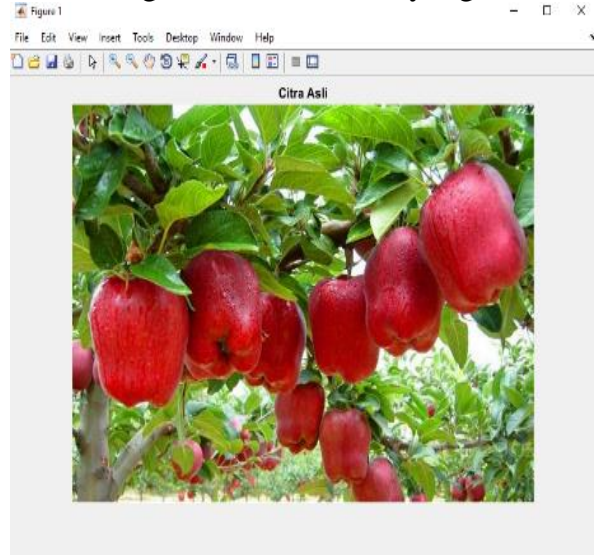

Gambar 3.3 (Gambar Citra Asli)

\section{Clustering Foreground dan Background dengan K-Means Clustering}

Pada proses clustering foreground (latar depan) dan background (latar belakang) dengan menggunakan metode K-Means Clustering, data awal yang diuji akan diproses menggunakan metode K-Means Clustering untuk membedakan antara foreground (latar depan) dan background (latar belakang). Dimana hanya terlihat buah apel pada clustering foreground (latar depan) dan hanya terlihat daun-daun pada background (latar belakang).

\section{Hasil Output Clustering Foreground}

Hasil yang ditampilkan setelah data awal diuji dengan menggunakan metode K-Means Clustering maka hasil yang akan ditampilkan yaitu terlihat perbedaan antara foreground (latar depan) dan background (latar belakang). Pada clustering foreground (latar depan) maka hanya buah apel saja yang akan tampak, sedangkan daun-daun akan dihitamkan untuk membedakan antara foreground (latar depan) dan background (latar belakang).

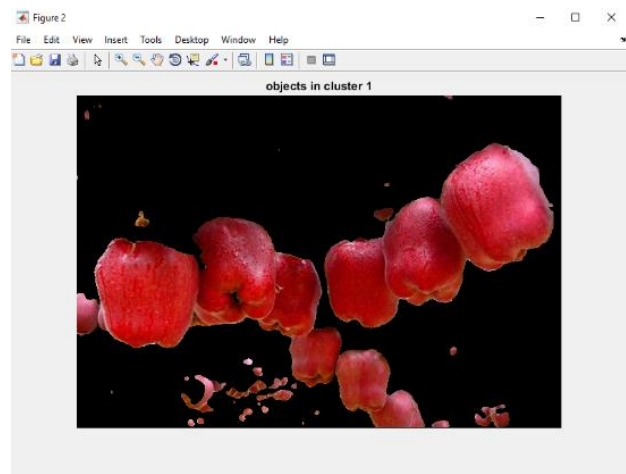

Gambar 3.4 (Clustering Foreground)

\section{E. Hasil Output Clustering Background}

Hasil yang ditampilkan setelah data awal diuji dengan menggunakan metode $\mathrm{K}$-Means Clustering maka hasil yang akan ditampilkan yaitu terlihat perbedaan antara foreground (latar depan) dan background (latar belakang). Pada clustering background (latar belakang) maka hanya daun-daun saja yang akan tampak, sedangkan buah apel akan dihitamkan untuk membedakan antara foreground (latar depan) dan background (latar belakang).

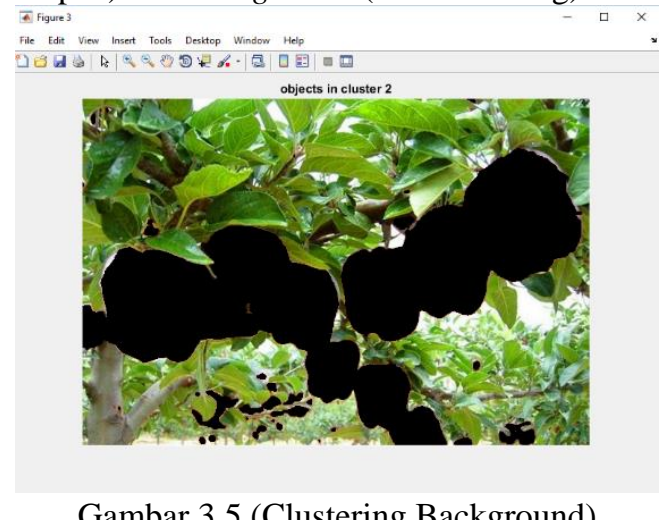

\section{HASIL}

Hasil yang akan ditampilkan pada penelitian ini yaitu pada figure 1 akan menampilkan citra asli yang akan diuji. Pada fihure2 akan menampilkan hasil yaitu clustering background (latar belakang) maka hanya daun-daun saja yang akan tampak, sedangkan buah apel akan dihitamkan untuk membedakan antara foreground (latar depan) dan background (latar belakang). Pada figure 3 akan menampilkan hasil yaitu clustering background (latar belakang) maka hanya daun-daun saja yang akan tampak, sedangkan buah apel akan dihitamkan untuk membedakan antara foreground (latar depan) dan background (latar belakang). 


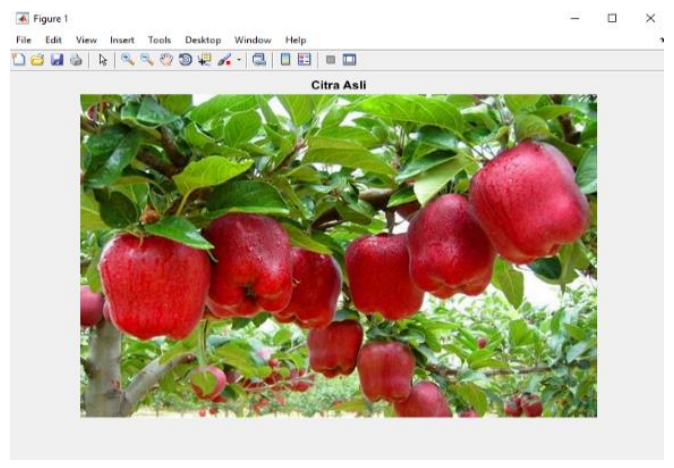

Gambar 4.1 (Clustering Foreground)

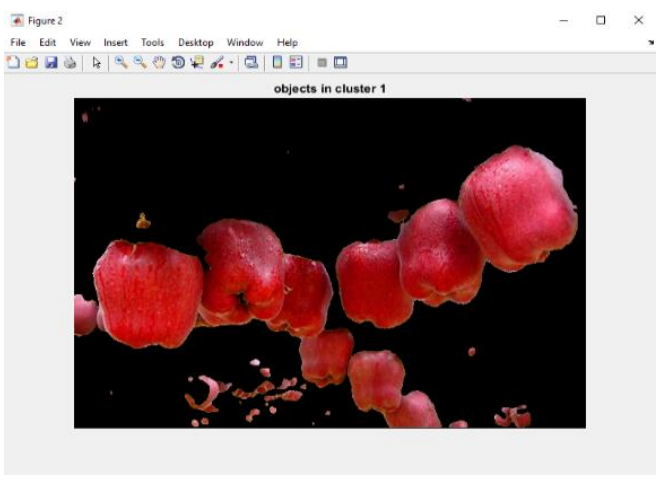

Gambar 4.2 (Clustering Foreground)

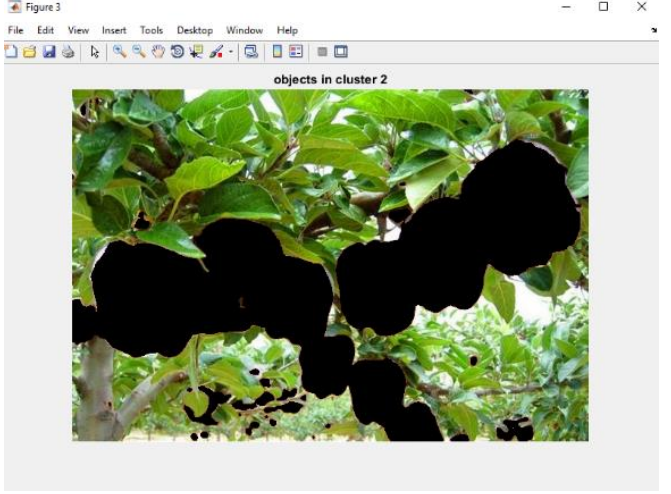

Gambar 4.3 (Clustering Background)

\section{KESIMPULAN}

1. Foreground dalam bahasa Indonesia berarti latar depan. Jika background terlihat dibagian belakang dari objek utama, maka foreground sudah pasti berada dibagian depan objek

2. Background dalam bahasa Indonesia berarti latar belakang. Dalam sebuah foto dipastikan memiliki sebuah latar belakang dari objek utama

3. Sebuah cluster adalah suatu kumpulan data yang mirip dengan lainnya atau ketidakmiripan data pada kelompok lain

4. Pada clustering background (latar belakang) maka hanya daun-daun saja yang akan tampak, sedangkan buah apel akan dihitamkan untuk membedakan antara foreground (latar depan) dan background (latar belakang)

5. Pada clustering background (latar belakang) maka hanya daun-daun saja yang akan tampak, sedangkan buah apel akan dihitamkan untuk membedakan antara foreground (latar depan) dan background (latar belakang)

\section{REFERENSI}

Agustin, F. E. M., Fitria, A., \& S, A. H. (2015). Implementasi Algoritma K-Means untuk Menentukan Kelompok Pengayaan Materi Mata Pelajaran Ujian Nasional (Studi Kasus: SMP Negeri 101 Jakarta). JTI (Jurnal Teknik Informatika) UIN Syarif Hidayatullah, 73-78.

Ediyanto, Mara, M. N., \& Satyahadewi, N. (2013). Pengklasifikasian Karakteristik Dengan Metod K-Means Cluster Analysis. Buletin Ilmiah, 02(2), 133-136.

Iswahyudi, C. (2010). Prototype Aplikasi Untuk Mengukur Kematangan Buah Apel. Jurnal Teknologi, 3, 107-112.

Wahyudi, N., Suhartono, V., \& Pramunendar, R. A. (2018). Background Subtraction Berbasis Self Organizing Map Untuk Deteksi Objek Bergerak. Systemic: Information System and Informatics Journal, 1(1), 42-51. https://doi.org/10.29080/systemic.v1i1.283 